\title{
5th INTERNATIONAL SCIENTIFIC CONFERENCE ON "EXERCISE AND QUALITY OF LIFE"
}

\author{
Novi Sad, Serbia, 11-13 April, 2019
}

A delegation from the Institute for Kinesiology Research attended the hospitable EQOL2019 in Novi Sad, organised by the Faculty of Sports and Physical Education of the University of Novi Sad. The plenary lectures of the conference covered various aspects within the subtopic 'from active childhood to healthy aging' in a very informative way: Wlodzimierz Starosta: Model of children's comprehensive movement education in a family as a fundament of healthy, physically active, successful and long life; Antonino Bianco: Field-based tests for the assessment of physical fitness in youth practicing sports: a systematic review within the ESA program; James S. Skinner: Exercise and quality of life in the elderly; Francisco B. Ortega: Fitter kids for a healthier adult society; Jozsef Betlehem: How can health literacy influence health status?; Jorunn Sundgot-Borgen: Exercise and quality of life in healthy adolescents, women with eating disorders and female elite athletes; Dejan Magoc: Impact of 5-2-1-0: a community-based childhood obesity prevention initiative; Sanja Music Milanovic: Physical (in)activity in early school-age: What are we doing wrong?; Visnja Djordjic: The post-milennials' lifestyle and what physical education can do about it?; Sanja Salaj: Physical activity and motor skills in preschool children; Finn Berggren: HEPA Europe - Before - Now - and???.

The conference allowed sufficient time for the oral presentations of both the invited speakers and work sessions, as well for poster sessions, where young and old could gather and discuss the themes.

From the main lectures, it was obvious that there is a role for attendees and organisers to raise awareness of the importance of physical activity during primary school periods, to battle sedentary lifestyles, and to consider physical activity as an integrated element of obligatory academic courses. HEPA Europe, a network of organisations recognized by WHO which emphasises health-enhancing physical activity, could have an important role in this (for more on HEPA Europe visit: http://www.hepaeurope2019. org/). From this perspective, it seems that new field-based tests for the assessment of physical activity for young people might even be of interest for (early) detection of cognitive and physical disabilities in children.

The abstracts of the conference have been published in BMC Sports Science, Medicine and Rehabilitation, Volume 11, Supplement 1 (https://doi.org/10.1186/s13102019-0119-7), while more details of the conference and its associated journal can be found elsewhere (http://eqol.rs and www.eqoljournal.com). The well-organised conference is highly commended for its invitation to renowned academic speakers, and for attracting several hundred participants who had the chance to share knowledge in a stimulating environment, which was especially rewarding for young researchers. 


\title{
5. MEDNARODNA ZNANSTVENA KONFERENCA »EXERCISE AND QUALITY OF LIFE«
}

\author{
Novi Sad, Srbija, 11.-13. april 2019
}

Sodelavci Inštituta za kineziološke raziskave ZRS Koper so se že tradicionalno udeležili 5. EQOL2019 konference v gostoljubnem Novem Sadu, ki jo je organizirala Fakulteta za šport in telesno vzgojo Univerze v Novem Sadu. Plenarna predavanja konference: Wlodzimierz Starosta: Model of children's comprehensive movement education in a family as a fundament of healthy, physically active, successful and long life; Antonino Bianco: Field-based tests for the assessment of physical fitness in youth practicing sports: a systematic review within the ESA program; James S. Skinner: Exercise and quality of life in the elderly; Francisco B. Ortega: Fitter kids for a healthier adult society; Jozsef Betlehem: How can health literacy influence health status?; Jorunn Sundgot-Borgen: Exercise and quality of life in healthy adolescents, women with eating disorders and female elite athletes; Dejan Magoc: Impact of 5-2-1-0: a community-based childhood obesity prevention initiative; Sanja Music Milanovic: Physical (in)activity in early school-age: What are we doing wrong?; Visnja Djordjic: The post-milennials' lifestyle and what physical education can do about it?; Sanja Salaj: Physical activity and motor skills in preschool children in Finn Berggren: HEPA Europe - Before - Now - and ??? so na zelo informativen način zajemala različne vidike letošnje glavne teme "Od aktivnega otroštva do zdravega staranja".

Konferenca je obsegala tako govorne predstavitve aktivnih udeležencev, kot tudi sekcijo poster predstavitev, kjer je bilo več časa za razpravo namenjenega predvsem tistim, ki so šele na začetku akademske poti.

Plenarna predavanja so tudi tokrat opozarjala na očitno vlogo, ki jo imajo udeleženci in organizatorji konference pri ozaveščanju javnosti o pomenu gibalne/športne dejavnosti v osnovnošolskem obdobju, pri boju proti sedentarnemu življenjskemu slogu in pri upoštevanju telesne dejavnosti kot integriranega elementa v učnih načrtih. Pri tem bi lahko izpostavili pomembno vlogo mreže organizacij »HEPA Europe«, pod okriljem Svetovne zdravstvene organizacije, ki promovira gibalno/športno aktivnost za krepitev zdravja populacije (več o »HEPA Europe« na http://www.hepaeurope2019.org/). V tej smeri lahko razumemo tudi nove terenske teste za oceno GŠA za mlade, ki naj bi pripomogli k (zgodnjemu) odkrivanju kognitivnih in telesnih pomanjkljivosti pri otrocih.

Povzetki konference so bili objavljeni v reviji BMC Sports Science, Medicine and Rehabilitation, Volume 11 Supplement 1 (https://doi.org/10.1186/s13102-019-0119-7), več podrobnosti o konferenci in znanstveni reviji lahko najdete tudi na (http://eqol.rs in www.eqoljournal.com).

Dobra organizacija konference $\mathrm{z}$ aktualnimi predavanji priznanih strokovnjakov ter več kot 100 predstavljenimi prispevki, zagotavlja spodbudno okolje in dobro priporočilo za vse mlade raziskovalce, ki si želijo akademske rasti. 